\title{
CHANGE AND CONTINUITY AMONG THE BATOMBU SINCE 1900
}

\author{
Emmanuel Oladipo Ojo*
}

Sabi Joshua Bio ${ }^{* *}$

\begin{abstract}
Like elsewhere in Nigeria and Africa, the imposition of colonial rule on Batombuland and the incursion of western ideas produced profound socio-cultural, economic and political changes in the Batombu society. However, unlike several Nigerian and African peoples whose histories have received extensive scholarly attention, the history of the Batombu has attracted very little scholarly attention. Thus virtually neglected, the Batombu occupies a mere footnote position in the extant historiography of Nigeria. This is the gap this article seeks to fill. It examines the impact of colonialism and western civilisation on Batombu's political, social, economic and cultural institutions and concludes that as profound and far-reaching as these changes were some important aspects of the indigenous institutions and traditional practices of the people survived.
\end{abstract}

Keywords: Batombu, Nigeria, Africa, colonialism, institutions, change, continuity

\section{Introduction: A Note on the Batombu/Bariba}

Like some other Nigerian and African peoples who were severed from their kith and kin by the arbitrary boundaries drawn by European imperialists in their unrestrained quest to acquire colonies and consolidate their foothold in Africa, the Batombu are found in three West African States: Benin Republic, Nigeria and Togo. They are one of the dominant ethnic groups in Benin Republic (known as Dahomey up to 1975) where they constitute the fourth largest ethnic group and approximately a tenth of the population. ${ }^{1}$ Those in Nigeria are found in the north-central zone, between Kwara State and the Borgu section of Niger State. Nigeria's Batombuland consists of four districts: Gwanara, Okuta, Ilesha and Yashikira, each under its Emir. The Batombu are also found in parts of northern areas of Togo. ${ }^{2,3,4}$ The Murdocks put the population of the group in Togo at 23,000 and its entire population all over West Africa at well over a million. The last estimate tallies

\footnotetext{
"Emmanuel Oladipo Ojo, Associate Professor, Department of History \& International Studies, Ekiti State University, Ado Ekiti, Nigeria \& Visiting Scholar, Department of General History, Institute of Humanities, Siberian Federal University, Krasnoyarsk, Russia.

${ }^{* *}$ Sabi Joshua Bio, Ph.D., Department of History, Kwara State College of Education, Oro Kwara State, Nigeria ${ }^{1}$ Carole, Davies B. (ed.) 'Benin', Encyclopedia of African Diasporal. Origins, Experiences and Culture, (California: ABC-CLIO Inc. 2008): 156

${ }^{2}$ Haddock, N.L. "The Tones of Bariba", Phonetica: International Journal of Phonetic Science, 3, (1959), 90-95

${ }^{3}$ Batoma, Atoma. "Onomastics and Indirect Communication among the Kabre of Northern Togo", Nordic Journal of African Studies, 18(3), (2009), 215-234.

${ }^{4}$ Prunier Gérard "Évolution des Critères de definition ethnique en Ouganda" in Chrétien Jean-Pierre and Prunier Gérard (eds.), Les ethnies on tune histoire, (Paris: Karthala, 2003).
} 
with that of Davies although Lopiz ${ }^{5}$ opined that "there are approximately 600,000 Bariba, 500,000 of whom live in the territory of Benin". Anene ${ }^{6}$ opined that the Batombu are called Borgawa by the Hausa and Bariba by the Yoruba; it however appears that the people call themselves Batombu (plural) and Batonu (singular) and their language, Batonnum. It must be added however that other than themselves, both the people and their language are known as Bariba or Batonu elsewhere. ${ }^{7}$ While Greenberg ${ }^{8}$ and Roger and Dendo ${ }^{9}$ classify Bariba as a member of the Mossi-Grunshi sub family of the NigerCongo family of languages; Welmers $(1952: 82)^{10}$ says it belongs to "the Voltaic group of languages and bears very close similarities with some of the languages in the Voltaic group" while Lopiz ${ }^{11}$ asserts that Bariba belongs to the Gur family "geographically centered in Burkina Faso". The last assertion implies that the Bariba are found in four countries in West Africa. It however appears that this is an isolated claim - the most popular and generally accepted view is that the Bariba are found in three West African states.

Prior to the famous 1898 'race to Nikki' following which the Borgu Kingdom ${ }^{12}$ was partitioned between the British and French, the whole of Batombulay within Borgu in Nigeria where they were part and parcel of the old Borgu Kingdom (the Bariba being the principal inhabitants). However, Britain and France clashed over Borgu and only narrowly avoided war $^{13}$ by signing the Anglo-French Treaty of 14 June 1898 Article II of which provided thus:

The line of demarcation shall start from the Extremity of the present frontier on the $9^{\text {th }}$ degree of North latitude ad shall be draen northward So as to include in the British sphere, the Frontier of Bere and Okuta together with the towns of Ashigere and Bete. It would follow Generally the direction of Meridian $3^{\circ}$ east of Greenwich, then leaving Nikki and Sorounding districts with the French sphere, but will be deflected so as to touch the Niger at a point ten males to the north of the town of Illo, leaving within the British sphere are territory belonging to the province of Bussa and the district of Gomba. ${ }^{14}$

\footnotetext{
${ }^{5}$ Lopiz, M. Joan, "Bariba" in Skutsch, Carl (ed.), Encyclopaedia of the World's Minorities, 1, (New York \& London: Routledge, 2005): 187

${ }^{6}$ Anene, J.C.International Boundaries of Nigeria, 1885-1960: The Framework of an Emergent African State, (London: Longman, 1960):194

${ }^{7}$ Adekunle, O. Julius. Politics and Society in Nigeria's Middle Belt.Borgu and the Emergence of a Political IdentityI, (Trenton: Africa World Press Inc., 2004):156

${ }^{8}$ Greenberg, Joseph H. The Languages of Africa, (Indiana: Indiana University Press, 1963): 16,20

${ }^{9}$ Blench, Roger and Dendo, Mallam. "The Benue-Congo Languages: a Proposed Internal Classification:

Working Document" [Cambridge (printout), 2004]:1

${ }^{10}$ Wlemers, E. William. "Notes on the Structure of Bariba", Language, 28(1), (January-March, 1952):82-103

${ }^{11}$ Lopiz, M. Joan, "Bariba", Op.cit.

${ }^{12}$ The BorguKingdom stretched from the north-western part of present-day Nigeria to the north-eastern part of present-day Benin Republic. The kingdom became so powerful towards the turn of the 19th century that it was able to resist the invasion of the Fulani Jihads of Sokoto and Gwandu until the establishment of British colonial rule

${ }^{13}$ For a detailed examination of Anglo-French conflict in West Africa, see Claire Hirshfield (1979), The Diplomacy of Partition. Britain, France and the creation of Nigeria, 1890-1898, London: MartinusNijhoff. ${ }^{14}$ Tibeaderama, P.K. (1977), "The Dissolution of A Kingdom: The Independent District of Illo 1894-1914", Savannah, 6(1), 11-21
} 
Thus partitioned, the Batombu of Ilesha Baruba, Gwanaru, Okuta and Yashikiru fell under British control while Kpanetem, Wassatem, Banikparatem and Makaratemfell under the French. Consequently, the area that fell under British side became known as Nigerian Borgu, while the French side became French Borgu. Although, both sides have a lot in common ${ }^{15}$ however, this article concerns itself with the Batombu of north central Nigeria only - i.e. those found between Kwara State and the Borgu section of Niger State. The British (Nigeria) Borgu had undergone several administrative changes since 1900: it became Borgu province in 1907 while IIIo, Kaoje, Lafagu and Gandemi were separated from it and merged with the Sokoto province as compensation for land lost as a result of northern boundary adjustments. In 1915, Kunji, Rofia and Agwara in Northern Borgu were carved from Borgu and merged with Yauri emirate, and later Sokoto province. However, Agwara and Rofia Districts were later returned to Bussa in 1918 and 1927 respectively. Nigeria Borgu was, in 1967 and 1991, partitioned among Kwara, Kebbi and Niger States. Presently, the Bariba are found in Baruten and Kaiama Local Government Areas of Kwara State; Baruten Local Government Area of Niger State and Illo in Kebbi State. Thus, as a result of several administrative changes, the size and shape of the area occupied by the Bariba differed over time.

Nigeria Borgu, situated in the Guinea Savannah region with climatic features like tall grasses and scattered trees, stretches from $9^{\circ}$ and $12^{\circ}$ parallel latitude and longitude $1^{0}$ and $4^{0}$ east of the meridian. The Batombu has two main traditions of origins - the Kisra and the Suni-Baru traditions. The former relates that Kisra, the progenitor of the Batombu, migrated westwards from Saudi Arabia having refused to accept the reforms of Prophet Mohammed. ${ }^{16,17}$ After a stint in Borno, he was said to have moved westwards with his followers to the Niger area from where they subsequently moved to Borgu. ${ }^{18,19} \mathrm{He}$ was said to have fathered three children (all males):Woru, Sabi, Bio. The first, being the eldest succeeded Kisra and founded Illo, where he left his youngest brother, Biowhile Sabi moved down southwards to Nikki (generally believed to be the headquarters of the Batombu). Woru was said to have also later moved southeast-wards where he founded Bussa. A variant of this tradition relates that Kisraactually settled in Bussa and allowed his brothers to found and exercise authority in Nikki and Illo. It must be stated however that the first variant is the most popular among the Batombu. Indeed, the tradition of naming children in the manner of Kisra's continues among the Batombu till date: Woru, Sabi and Bio for the first, second and third sons respectively.

The most cursory glance at the tradition related above leaves a scientific historian with some unanswered questions. First is the personality of Kisra, the supposed progenitor of the Batombu. While the limitation of space cannot permit a fairy detailed analysis of the

\footnotetext{
${ }^{15}$ Some of the factors that account for the strong unity that exists among all Bariba groups across the West African subcontinent are the traditional political influence of Nikki; the long-term co-existence of these communities; language; the existence of several symbolic objects of veneration particularly the personality of mystical Kisra and the Goani, an important annual festival of aristocratic origins.

${ }^{16}$ Stewart,M. H."The Kisra Legend as Oral History”, The International Journal of. African Historical Studies, XIII(1), (1980),23-34

${ }^{17}$ Mathew,A. B. "The Kisra Legend” African Studies, 9(3), (1950),25, 144-147

${ }^{18}$ Mahmud, S. Saka."Effects of Modernization on Social Identity: The Borgu Case", unpublished B.Sc Dissertation, (Zaria: Ahmadu Bello University, June-1976): 16

${ }^{19}$ Sabikpasi, Umar Sarikin, (Emir of Yashikira), interview: $7^{\text {th }}$ September 2017
} 
personality and itinerary of Kisra here; suffice it to state that leading Arabic sources are unanimous that Kisrawas killed in c. 651 A.D. ${ }^{20}$ Yar-Shater, citing several primary and other Arabic sources, contended that Kisra Abarwiz had 18 sons and was killed by the Persians as a result of his high-handedness. According to him:

Kisrã treated people [his subjects] with contempt and regarded them with scorn in a manner no righteous and discerning monarch should adopt...[his] insolent pride and lack of respect for God reached the point that he gave orders to the man in charge of his personal guard of court called Zãdhãn Farrũ that he should kill every person held captive in any of his prisons; these persons were counted up and their number reached thirty-six thousand...Kistra incurred for himself the hatred of the subjects of his kingdom for various reasons...The Persians rose up against Kisra and killed him, aided by his [oldest] son, Shiruyah. ${ }^{21}$

Other scholars corroborate the above. Hazrat and Yusuf ${ }^{22}$ assert that Kisra, the Emperor of Persia, was killed as a result of his high-handedness and his refusal to embrace Islam. In the same vein, Ibn-e-Katheer ${ }^{23}$ opines that Kisra was "cut up...as a piece of meat is dismembered" and that "his murder occurred on the night of Tuesday, the tenth of Jumad Al Oola, in the Year 9 A.H.". If the above accounts with their unanimity on the murder of Kisra in Persia are anything to go by; one wonders which Kisra the Batombu tradition refers to. Moreover, the claim that Batombu was founded by Kisra, apparently an Arab, is very doubtful as there are no similarities in the culture, language, skin colour, etc of the Bariba and Arabs.

The second tradition of origin of the Batombu is the Suni-Baru tradition given by Lafia Hussaini. ${ }^{24}$ According to him, the Batombu are believed to have lived within the West African sub-region (possibly in Gao) and that Suni-Baru and his supporters left Songhai and moved towards Bussa, the eastern end of the Borgu Kingdom. At Bussa, Suni-Baru was recognized as ruler. ${ }^{25}$ SuniBaru was said to have been followed by the Homboriand Barga peoples. According to this tradition, Hombori went westwards while the Barga followed the River Niger to Nikkiberi and later to Batombuland. The Suni-Baro group was subsequently conquered by the Hombori who thereafter established themselves as rulers. According to this tradition, this was how the Wassangari (the ruling class) originated amongst the Bariba. Viewed from the Afro-centric autochthonous-latter migrants' perspective, the two traditions related above, though contradictory on the surface, do not really contradict; rather they corroborate each other. The Kisra myth is nothing more than an extension of the Hamitic hypothesis.

${ }^{20}$ Mautana, H. Mohammad and Kandhelvi, Yusuf (1999: translated by Bosworth, C.E.), The Lives of the Sahabah (translated by Atzal, M. Hoosen), n.d; n.p.:12

${ }^{21}$ Yar-Shater, Ehsan, The History of al-Tabai Vol. V.The Sãsanids, the byzantines, the Lakmids, and the Yemen, (New York: State University of New York Press, 1999):378-381

${ }^{22}$ Mautana, H. Mohammad and Kandhelvi, Yusuf (1999: translated by Bosworth, C.E.), The Lives of the Sahabah (translated by Atzal, M. Hoosen), n.d; n.p.:158

${ }^{23}$ Katheer, Ibn (n.d: translated by Darussalem Publishers), Life and Times of the Messengers, n.p: Darussalem Publishers.:45

${ }^{24}$ Hussaini, Lafia.The Batombu and their Culture, (Ilorin: Haytee Press \& Printing Co., 2003):14

${ }^{25}$ Ibid. 
Although, the African continent, like others, has been an active stage upon which the drama of human development and cultural differentiation has been acted since the beginning of history; until recently, the history of the continent, its culture as well as the potentials of its peoples have been a subject of monumental distortions, ridicule and outright denial. The Europeans opined that Blacks were racially, biologically and intellectual inferior to the Whites or Hermites. Amongst the leading Euro-centric writers who dismissed the possibility of African history was the German philosopher, W.F. Hegel, who contended that "Africa is no historical part of the world...it has no movement or development to exhibit". According to Hegel, any attempt at studying the history of Africa before the colonial enterprise would amount to "prying into the unrewarding gyrations of barbarous tribes in picturesque but irrelevant corners of the globe" 26 . In 1930, the British ethnologist, C.G. Seligman, postulated that "the civilizations of Africa are the civilizations of the Hermites". ${ }^{27}$ This postulation has since then been known as the Hamitic hypothesis. The implication of the above, as Markovitz has pointed out is that "Africans had no history, meaning that they did not change or progress or have science, art or inventions among themselves". ${ }^{28}$ Thus perceived as innately incapable of initiating or inventing anything useful, Africa was relegated to the bottom rung of human history and viewed as what Okon terms "pathological adjuncts of White societies". ${ }^{29}$ Trevor Roper, Regius Professor of Modern History at Oxford, re-echoed the above line of thought in 1963 when, in response to African students' demand for African history courses, he said "undergraduates, seduced, as always, by the changing breath of journalistic fashion, demand that they should be taught the history of black Africa perhaps, in the future, there will be some African history to teach, but at present there is none. There is only the history of the Europeans in Africa the rest is darkness and darkness is not a subject of history". ${ }^{30}$ Roper contended further that he did not deny that men existed in dark countries and dark centuries, nor that they had political life and culture, interesting to sociologists and anthropologists but that history was not "a mere phantasmagoria of changing shapes and costumes, of battles and conquests, dynasties and usurpations, social forms and social disintegration" which was the best Africa had. ${ }^{31}$

The above accounts for the Euro-centric view that virtually all Nigerian/African peoples originated/migrated from the amorphous 'east' variously supposed to be Egypt, Yemen, Nubia, Meroe or Persia. It is in this context that the 'eastern traditions of origins' of such Nigerian peoples as the Yoruba, Igbo, Hausa, etc should be understood. However, the Hamitic hypothesis has been thoroughly discredited and demolished such that today, as Okon has pointed out, "only the hopelessly uniformed can claim now that Africa has no history". ${ }^{32}$ Isichei has pointed out that "only two of Nigeria's peoples speak languages

\footnotetext{
${ }^{26}$ Uya, EdetOkon.African History. Some Problems in Methodology and Perspectives, (Calabar: CATS Publication, 2004):3

${ }^{27}$ Fage, J.D., A History of West Africa, (Cambridge: Cambridge University Press, 1969):7

${ }^{28}$ Markovitz, I.L. "Africa's Dual Heritage: Imperialism and Pre-Colonial Greatness" in Markovitz, I.L. (ed.), African Politics and Society, (New York: The Free Press, 1970)

${ }^{29}$ Ibid., p.3

${ }^{30}$ Poulsen, Sven, “African History: from a European to an African point of view", Kunapipi, 3(1),(1981),75-80

${ }^{31}$ Appiah, K. Anthony.“'Africa: The Hidden History”, The New York Review of Books, $17^{\text {th }}$ December 1998

Issue: 12

${ }^{32}$ Uya, EdetOkon.African History.Op.cit.(2004):6
} 
which suggest an origin far beyond the borders of Nigeria: the Shauwa Arabs who live in south of Lake Chad, and the Fulani". ${ }^{33}$ Corroborating the above, Obayemi ${ }^{34}$ contended that virtually all Nigerian peoples, save the two groups mentioned above, originated from the Niger-Benue Confluence area in Nigeria and migrated in several waves to their present abodes. Deploying linguistic evidence in support of the above, Williamson ${ }^{35}$ asserted that nearly all Nigerian languages belong to the Benue-Congo family of languages, which spread across a vast area of West Africa including many languages in Nigeria; the Fon languages in Benin Republic; Ewe, Fante and Asante in Ghana; Baule and Bate in Ivory Coast (Côte d'Ivoire); and Bassa and Kru in Liberia. Indeed, Atanda (1980a:4) was emphatic that "none of the Nigerian peoples speak a Hamitic language". ${ }^{36}$ It has thus been asserted that the speakers of the Benue-Congo languages originated from the Niger-Benue Confluence and migrated in waves to all the places they are now found. Pieced together, available evidence support this postulation. For example, Frobenius ${ }^{37}$ account asserts that the Borgu people (including the Batombu) under Kisra migrated from Badar, near Mecca and that they "broke off into many sections". Also, Temple $^{38}$ (1919:45) who supported the Badar migration thesis argued that the immigrants decided to settle down when they reached River Niger. It seems safe, therefore, to assert that the ancestors of the Batombu migrated from the Niger-Benue Confluence in waves. Just as the Obatala / Oduduwa tradition has now been generally accepted to represent the end of an era and the beginning of another in the history of the Yoruba $;{ }^{39}$ so is the Kisra tradition: Kisra represents the autochthonous settlers in Batombuland who left the NigerBenue Confluence area in earlier waves of migration while the Wansangari group represents the better-armed latter immigrants who super-imposed themselves on the autochthonous settlers. This assertion agrees with that of Lopiz who opine that "the Bariba are descendants of different population movement...the Wansangari warriors imposed themselves on the Bariba area progressively from the fourteenth to the eighteenth centuries". ${ }^{40}$ In the same vein, Mangut asserts that:

all informants interviewed in and around New Bussa (primary sources), relating to the origin of the Borgu people only provided information relating to the origin of the ruling aristocracy popularly known as Wasangari. It therefore

\footnotetext{
${ }^{33}$ Elizabeth A. Isichei, A History of Nigeria, (London: Longman, 1983):5.

${ }^{34}$ Obayemi, Ade. "The Yoruba and Edo-speaking Peoples and Their Neighbours Before 1600" in Ajayi J.F.A. \& Crowder, Michael (eds.), History of West Africa, Vol. II, (London: Longman, 1985):255

${ }^{35}$ Williamson, Kay (1989), "Niger-Congo Overview" and "Benue-Congo Overview" in Bendor-SamuelJohn (ed.), The Niger Congo Languages, (Lanham: University Press of America, 1989), 3-46 and 246-274

${ }^{36}$ Atanda, J.A. "The Historian and the Problem of Origin of Peoples in Nigerian Society", Journal of the Historical Society of Nigeria, (1980a)10(3):4,33-41

${ }^{37}$ Frobenius, Leo.The voice of Africa: being an account of the travels of the German Inner African Exploration Expedition in the years 1910-1912, (London: Hutchinson,1913):35

${ }^{38}$ Temple, O. (1919), Notes on the Tribes, Provinces, Emirates and States of the Northern Provinces of Nigeria. (Cape Town: Argus Printing and Publishing Co Ltd., 1919):45

${ }^{39}$ E.O. Ojo (2001; 2002 and 2006) has dealt with this extensively. See his "The Origins of the Yorubas within the Context of the Hamitic Hypothesis" UNAD Journal of Education, 2(1), 2001, 69-74; "The Creation and Migration Myths of Yoruba Origins: An Appraisal" AAU: African Studies Review, 1(1), 2002, 85-96 and "Linguistics: An Indispensable Tool in the Reconstruction of Early Nigerian History", AJOLL: Ado Journal of Languages and Linguistics, 1(1), (2006), 21-34.

${ }^{40}$ Ibid.
} 
appears as if there were certain indigenous groups in which oral traditions relating to them have been deliberately ignored or have since been lost to time $\mathrm{e}^{41}$

Available pieces of evidence seem to agree that the founder or founders of the Batombu might have been a group of horse-riding, politically and militarily superior invaders who imposed their authority over the indigenous peoples, but being inferior in numbers, they adopted the language of the indigenous population. ${ }^{42}$

\section{British Colonial Enterprise, Change and Continuity in Batombuland}

The old treaties are dead; you have killed them. Now these are the words which I the High Commissioner have to say for the future. The Fulani in old times, under Dan Fodio, conquered this country. They took the right to rule over it, to levy taxes, to depose kings and create kings. They in turn have lost their rule which has come into the hand of the hands of the British. All these things, which I have said the Fulani took the right to do, now pass to the British. ${ }^{43,44,45,46}$

With the above pronouncement by Fredrick Lugard at the installation of Mohammadu Attahiru II as the 'colonial emir' of Sokoto on 21 March 1903, the imposition of foreign rule or what Herbst calls 'the dawn of colonial rule' in Northern Nigeria effectively began even though pockets of resistance to the British administration continued. ${ }^{47}$ Thus, Batombuland, like other ethnic groups in Northern Nigeria, came under British colonial rule. This imposition had far-reaching implications for the indigenous political, social, economic and cultural institutions of the people. However, as overwhelming and profound as the impacts of colonialism and westernisation were; some aspects of the traditional institutions of the Bariba survived and continue to the present. Our analysis begins with changes and continuity in the socio-cultural sphere.

Arowolo ${ }^{48}$ defines culture as the totality of a set of bequeathed ideas, belief system, values and norms which constitute the common bases of generally agreed social action. One of the most catastrophic consequences of colonialism in Batombuland was the distortion (westernisation) of the culture of the people. ${ }^{49}$ Before the advent of colonialism and

\footnotetext{
${ }^{41}$ Mangut, N. Benedicta. "Preliminary Investigations of the Origin and Historical Traditions of the Borgu in Niger State of Nigeria" Journal of Tourism and Heritage Studies, 2(2),(2013), 1-13

${ }^{42}$ Levtzion, N. Muslims and Chiefs in West Africa.(Oxford: Clarendon Press, 1968):17

${ }^{43}$ Oluniyi, Olufemi (2017), Reconciliation in Northern Nigeria. The Space for Public Apology, (Lagos: Frontier Press, 2017)

${ }^{44}$ Williams, Stephanie.Running the Show. Governors of the British Empire, (London: Penguin, 2011):146-7, 289

${ }^{45}$ Lockhart, J. Bruce.A Sailor in the Sahara: The Life and Travels in Africa of Hugh Clapperton, Commander

$P N$, (London \& New York: I.B. Tauris, 2008):269

${ }^{46}$ Herbst, Jeffrey.States and Power in Africa. Comparative Lessons in Authority and Control, (Princeton \& Oxford: Princeton University Press, 2004):83

${ }^{47}$ For a detailed examination of some of the resistance movements, see Paul E. Lovejoy \& J.S. Hogendorn.

"Revolutionary Madhism and Resistance to Colonial Rule in the Sokoto Caliphate, 1905-6", The Journal of African History, 31(2), (1990), 217-244.

${ }^{48}$ Arowolo, Dare. "The Effects of Western Civilization and Culture in Africa", Afro-Asian Journal of Social Sciences, 1(IV), (2010):12-24.

${ }^{49}$ Aboyeji, S. Oye. "The Impact of Colonial Rule on Indigenous Culture and Institutions of Isin Land”, M.A.

Thesis, (University of Ilorin, 2005):121
} 
western civilisation, the Batombu worshipped the Wooru, Buи and Shinagura deities. Wooru was worshipped mostly by hunters while sacrifices were offered to Вии in the event of drought. Expectedly, the imposition of colonialism and introduction of western civilization waned the influence of these gods, considerably reduced the number of their adherents and worshippers and contributed to instability of traditional Batombu society. ${ }^{50}$ The introduction of schools by the Christian Missionaries and the acquisition of Western education by some members of the Batombu society led to the emergence of elites who no longer regarded their culture and now saw themselves as superior to their "nonwesternised' elite. Their 'sophistication' made them to despise and abhor traditional cultural practices particularly the worship of Buи, Shinagura and Biokitiri. Thus, colonialism brought with it Christianity and a new concept of God who was prepared to forgive anyone who showed penitence and sought forgiveness after committing a crime. This removed or eroded the fear of instant retribution from the gods. The result of the disregard and outright contempt for traditional norms and values, gods and deities became a sort of license to engage in vices that instant retribution from the gods once prevented. Moreover, the influence and authority of the priests and diviners whose authority rested on traditional religious beliefs waned. In other words, the introduction of western education / civilisation reduced the acceptance, reverence and importance of traditional religious observances which had for a long time commanded the obedience and awe of the people. Furthermore, in traditional Batombu society, young people stooped to greet elders as a mark of respect; however, western educated elites changed the trend by resorting to shaking hands or refusing to stoop while greeting elders. Similarly, European cultural traits and values such as dressing, greeting, eating habit and other behavioural attitudes were emulated (for example taako and bante were discarded for European style dressing). This scenario and phenomenon was repulsive to those members of the Batombu society who still remained 'traditional' thus leading to societal stratification which sometimes led to conflict and ill feelings. ${ }^{51}$

Before the imposition of colonial rule and the introduction and spread of western civilisation in Batombuland, the acknowledgement of the curative and preventive potency of charms and traditional medicine for various ailments was ubiquitous. Indeed, the Bariba were known all over the entity now known as Nigeria as 'charm makers' such that famous Bariba 'traditional doctors' and charm/amulets makers were patronized from far and near. The effectiveness of their charms was probably responsible for the Baribas' reputation as archers and guards. Until very recently, all over Nigeria, the Bariba were preferred above other groups as night guards as their charms and amulets supposedly made them invincible and brought protection to the lives, properties and neighbourhoods they watched over. The introduction of orthodox medicine diminished the patronage of Baribas' 'traditional doctors'. Also, the emergence of neighborhood policing as well as sundry misdemeanors by some of the Bariba hired as night guards have considerably waned the demand for Baribas as night guards. ${ }^{52}$ However, in spite of the prevalence of orthodox medicine, traditional medicine has continued to play prominent role in health

\footnotetext{
${ }^{50}$ Alade,C.Aderele."Some Aspects of Yoruba Culture in Diaspora" in Ogunremi, Charles Aderele\&AdeniranBiodun(eds) Culture and Society in Nigeria, (Ibadan: Rex Charles Publications, 1988):209

${ }^{51}$ Kilishi, O. Abdullahi, (Chief of Gure), interview: ${ }^{\text {nd }}$ October 2017

${ }^{52}$ Sabikpasi, Umar Sarikin, (Emir of Yashikira), interview: $7^{\text {th }}$ September 2017
} 
care delivery of the Batombu people. Till date, an important percentage of the Bariba still prefers traditional to orthodox medicine. Indeed, some of them opine that the former, rather than the latter, could effectively cure psychiatric-related problems and seizures among others and ward off 'dark power attacks' or stop the afflictions inflicted by them. ${ }^{53}$ Moreover, in a country where doctor-population ratio stands at 1 to 4,000 , it is almost inevitable that citizens would seek alternative sources of medi-care. The Medical and Dental Consultants Association of Nigeria recently described the country's doctorpopulation ratio as appalling and unacceptable. ${ }^{54}$ Another factor that has aided the survival and continuity of traditional medicine among the Batombu is inadequate health facilities and the lopsided nature of their distribution: health facilities, most of which lack drugs, personnel and equipment are located in the urban areas thus promoting the patronage of traditional medicine in the rural areas. ${ }^{55}$ In the area of religion, it is important to note that the adherents of the 'White man's faith' continue to consult their ancestral gods, oracles and deities in case of severe sickness, ill-luck or misfortune. Indeed, till date, the Batombu are conscious of the potency and powers of the gods and are sometimes un-persuaded that the gods are imaginary and powerless. Ironically, in some cases, Christians and Muslims contribute money to perform certain traditional cleansing, rituals and rites to appease the gods or to seek favours like rain, good harvest, healing, children, etc from them. ${ }^{56}$

Another important aspect of the culture of the Batombu that was overwhelmed by colonialism and westernisation was facial marks and tattoo. Kuroru (cutting of the top of the nose) and kpelle (three parallel cuts on both sides of the cheek) were very popular among the Batombu before the advent of colonialism and westernisation. The colonial administration discouraged these practices citing the risk of infection and the excruciating pain suffered by those who engaged in them. The above, coupled with 'civilisation', rendered these acts 'anti-social' and were consequently abandoned by many Bariba. ${ }^{57}$ Today, it is a rarity to find Batombu young men and women bearing facial marks and tattoos. Moreover, colonialism and other foreign influences led to name-confusion in the Batombu society. Given the waning of facial marks and tattoos, Batombu names, which would have served as a prominent mark of identification of the Bariba, became either Islamized or anglicized. In traditional Baatonu society, names were given by any relative of the new born. There were three categories of names: names in appreciation of idols and festivals; two, names in order of birth; and three, names in remembrance of family members, place of birth or prevailing circumstances during birth. Examples of the first are Tabe, Siano, Taku, Weragi (for males) and Dangana, Deeru, etc (for females). Names in order of birth include Woru, Sabi, Bio, Bonni, Sanni, Woru-Mere, Sabi-Mere (for the first to the seventh males respectively) and Yon, Bona, Bake, Buyon, Yon-Mere, BonaMere for the first to the sixth female children respectively. Names in remembrance of

\footnotetext{
${ }^{53}$ Oyoru, Ahmadu, Gwanaru, interview: $5^{\text {th }}$ September 2017

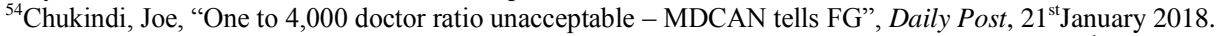
See also "Doctor-People Ratio Improving, Shortage of Specialists Persists", Financial Tribune, $7^{\text {th }}$ February 2017 retrieved from https://financialtribune.com/articles/people/59036/doctor-people-ratio-improving-shortageof-specialists-persists(Accessed on $10^{\text {th }}$ December 2017)

${ }^{55}$ Idris, Abdullahi, the Protocol Chief (Sinadunwiru) of Okuta, interview: $20^{\text {th }}$ October 2017

${ }^{56}$ Sabikpasi, Op.cit.

${ }^{57}$ Negri,Eve."Tribal Marks: A Decorative Scars and Painted Patterns" Nigeria Magazine, (1964),10:5
} 
family members include Bakenduro, Tourenduro, Gunungobi (males) and Baankuro, Gununkuro, Takun-Kuro (females) while those depicting prevailing circumstances during birth are Worusua, Bona sua (born on the road); Worudwaru, Bona dwaru (born at river); Worugura, Yongura (born when raining); Bansu (born after the death of father); Worugouraa (male child born after many girls); Yongouraa (girl child born after many boys). In addition to the three categories mentioned above, there were also clan and subclan names. Some of the aboriginal Batombu clans bore names like Tamba, Doko, Toku, Gawe, Mansa, Buara, Birso, Baatia, Worudeke, Gbeeru, Daki, Baku (males) while females bore such names as Deeru, Kaano, Itoo, Natoo, Tanson, Kpaare, Yenu, Sebegi among others. In the sub-clan of Kenubu names like Oyoru, Ayara, Komilafia, Sokobasi, Sinaworu, Yirugi, Sinabio, Meyemi, Mafara and Kenken (male) and Nangi, Woore, Samanse, Bara, and Mangu (female) were famous. Famous manes among the Wassangari included Lafia (heron), Saka (acacia tree), Yaru (buffalo), Sime (crocodile), Gunu (lion), Koto (hyenna), Kora (river Niger) for males and Yaaki, Kpayero, Gandigi, etc for females. The Moraru clan bore names like Asaburu, Daba, Weene (male) and Yeeka, Bona Sani and Yonbio (female). Today, however, owing to westernisation, the above names are rarities: indigenous names have almost completely given way to names like Yusuf Mohammed, Ibrahim Issa, Mohammed Lawal Yusuf, Victor Joshua, Helen John, Lawrence Thomas, Matthew Jacobs, Joshua Emmanuel among many others. However, some still preserve and promote their native names mostly by making them middle names hence names like Ezekiel Woru Thomas, Eunice Bona Abraham, Ibrahim Woru Abdullahi, Said Bio Ibrahim, etc. The overall effect of this is the loss or obfuscation of identity. ${ }^{58}$

Western influence also produced remarkable changes in the area of traditional music and literature with varying degrees of survival and continuity. Music was employed for entertainment on occasions like marriage, naming and funeral, and installation/coronation ceremonies. Today, many Bariba have replaced moroku- their traditional music which served entertainment and encouragement purposes - with jazz and pop songs. In any case, the traditional music industry is still active particularly during coronation and installation ceremonies, the annual Goanifestival and sometimes at state functions. Also, the griots, $(B a r o b u)$ reputed for their penetrating knowledge of court history and oral traditions of the people are irreplaceable and still function very prominently as the custodians and 'house of knowledge' of the traditions and culture of the Bariba. Closely related to the above is dressing. In traditional Batombusociety, men wore taako; women wore barubekuruwhile princes wore taakogona and taakokpakpene. ${ }^{59}$ Taako, which has waned in significance and use, is woven locally from local fabric material. In traditional Batombu society, children between ages five and ten wore pants called petu and graduated to the use of knickers called komisa at adolescent. Cap had special significance in Batombu culture - it was used to identify the class/status of an individual. Cap made from white taako(bent backwards)was worn exclusively by chiefs and other title holders. The furogona (cap made of black and white dotted taako cloth) had spiritual and political importance and was worn by individuals who were renowned for traditional herbal

\footnotetext{
${ }^{58}$ Kilishi, O. Abdullahi, (Chief of Gure), interview: $2{ }^{\text {nd }}$ October 2017

${ }^{59}$ Hussaini, Lafia. The Batombu and their Culture, (Ilorin: Haytee Press \& Printing Co., 2003):45
} 
medicine. ${ }^{60}$ The rulers also had their peculiar cap - a red long cap, with many yards of fabric wound round it. Monarchs wore a big garment filled with a loose gown of rich embroidery called guru musur while their foot wear was usually a heel-less shippers. ${ }^{61}$ Generally, traditional dressing has given way to modern ones although all the categories of traditional attires mentioned above are still worn during special occasions like coronation and other traditional festivals and ceremonies. On the other hand however, it is worthy of note that Batombu monarchs still maintain their traditional mode of dressing described above. ${ }^{62}$

Colonialism also engendered profound changes in the economy of the Bariba. The traditional, pre-colonial economy of Batombuland, as elsewhere, was predominantly food crop farming supplemented with hunting, animal husbandry and local crafts whose production was based on indigenous technology. ${ }^{63}$ Land was fertile, available and communally owned, hence every member of the society had unrestricted access to it while blacksmithing provided the basic local tools and implements needed for farming. The imposition of colonialism and the spread of western culture had far-reaching implications for farming and other indigenous economic activities. In the first place, many people went in search of white collar jobs and gave up farming which now became an 'old folks job' One of the consequences of this was a sharp decline in the scale of farming and food production. Also, indigenous technology suffered as attention shifted from traditional farming implements like hoe, cutlass, knife, etc to European-type tools. ${ }^{64}$ The local weaving industry was not spared as attention shifted away from indigenous to western dresses and from local yarns to imported ones. In the same vein, indigenous utilities and utensils like clay pot, bowl, black soap, basket, trap etc suffered sharp decline ${ }^{65}$ The quest to dominate and control the economy of Africa was one of the immediate causes of imperialism; consequently, as was the case elsewhere, following the 'pacification' of Batombuland, British colonial officials made conscious and sustained efforts at steering attention away from the cultivation of food to cash crops. However, as profound and far-reaching as the above changes were, till date, the Bariba still continue to cultivate indigenous crops; engage in the manufacture and production of indigenous farming tools and implements; promote hand-woven fabrics and continue to deploy traditional tools like tebo (hoe), gban (axe), gbansikiru (a long stick with iron at the edge used for digging yam) and adaru (cutlass) in their farming activities.

Autochthonous Bariba monarchical political system was headed by the descendants of earliest migrants from the Niger-Benue Confluence area. Their court ensured societal peace, stability, cohesion and harmony. With the arrival of the Wassangari group, the Batombu society became transformed from a homogenous society to composite one or what Lopiz calls 'a complex whole'. In addition to the Bariba and the Wassangari, there were also the Boko and Mokole speakers as well as the Fulani and Gando ethnic groups.

\footnotetext{
${ }^{60} \mathrm{Ibid}$.

${ }^{61}$ Ibid.

${ }^{62}$ Sabikpasi, Umar Sarikin, (Emir of Yashikira), interview: $7^{\text {th }}$ September 2017

${ }^{63}$ Mason, Michael."Population Density and Slave Raiding: The Case of the Middle Belt ofNigeria", Journal of African History.10(4) (1969):551-556

${ }^{64}$ Ibid.

${ }^{65}$ Damakowo, B. Sime (2017), Interview: $22^{\text {nd }}$ October 2017
} 
Following their conquest of the autochthonous settlers, political authority passed to the Wassangari group with Sinaboko (higher king) becoming the political head while the indigenous chiefs were "concerned with religious and symbolic systems developing a linking function between the newcomers and local divinities". ${ }^{66}$ The autochthonous Bariba were differentiated from the Wassangari in the order of their socio-political practices and roles. In effect, the indigenous Bariba occupied lower socio-political status in the arrangement that ensued. The Wassangari in turn lost their socio-political status following the 'pacification' and imposition of colonial rule on Batombuland. Thus, vital political appointments, hitherto the exclusive reserve of the king-makers and the king's court, were now subject to the approval of higher authorities, particularly District Officers. The regional government inherited this right at independence in 1960 and it is now the prerogative of the Governor to confirm the appointment of the Emirs whose courts create chieftaincy titles and appoint lesser chiefs for administrative, loyalty and pecuniary purposes. ${ }^{67}$ Closely related to the above is dispensation of justice. In traditional Batombu society, disputes and petty quarrels and other social misdemeanors were settled and handled at the family level while issues that could not be settled by the family head or verdicts which the parties involved appealed against were referred to the village head while the king's court was the highest court of appeal. Vices such as laziness and lying were punished by exclusion or suspension from age-grade functions. In theft cases, the Shinagura deity was invoked for sanction especially when the culprit denied involvement. However, with the emergence of Area and Customary Courts following the imposition of colonial rule; government appointed judges became the dispensers of justice. Till date, however, family and village heads as well as the king continue to play prominent roles in the dispensation of justice while the age grades still perform different socio-cultural functions.

\section{Conclusion}

This paper highlights some of the changes that occurred in the twentieth century history of the Batombu following the 'pacification' and imposition of colonial rule on Northern Nigeria. The paper pointed out that the traditional socio-cultural, political and economic systems and institutions of the Batombu were assailed by foreign influences and practices. Land, readily available and fertile, became under-utilised as young folks went in search of white collar jobs while farming became an 'old folk's job'. The consequence was a sharp decline in the quantity of food production. Also, the imperialists' agricultural policies which favoured the cultivation and production of cash crops for the use of the metropole, coupled with the prospects of increased earnings by local farmers, swayed people away from the cultivation of food crops. The traditional cultural setting of the Bariba also witnessed profound changes as western music rivaled and overshadowed indigenous music while many gave up their indigenous names in favour of high sounding anglicized names. Also, Christianity and western education became the vogue thus depleting the ranks of the adherents of traditional religion while monogamy gained some foothold. Indigenous technology was stifled due to the availability, popularity and effectiveness of western goods, tools and implements. Also, the occupiers of traditional

${ }^{66}$ Lopiz, M. Joan, "Bariba", Op.cit.

${ }^{67}$ Idris, Abdullahi, the Protocol Chief, Op.cit. 
political space suffered degradation as they became subservient to British colonial administrators.

However, as profound, wide-spread and far-reaching as these changes were, they did not wholly obliterate the traditional practices of the people. Thus, farming remained (and continues to remain) the dominant economic activity of the Batombu with a fairly widespread use of traditional farming implements. In addition, traditional music continued to be treasured by some Bariba while many still preserve and promote indigenous names and other modes of identification. The annual Goani festive is still popular and un-assailed. Indeed, the banning of the festival for the Bariba in French Borgu by the administration of MathieuKérékou ${ }^{68}$ in 1974 led to a mass migration of Bariba from the French to British Borgu until 1981 when it was unbanned (Lopiz:188). Till date, many Bariba folks still treasure traditional utensils like earthen pot for storage of drinking water while many are polygamists. The lopsidedness in the citing of modern health facilities and other sundry limitations as well as the Baribas' 'faith' in the preventive and curative potency of local herbs continue to ensure patronage of traditional medicine. Till date, many Bariba are of the opinion that ailments like leprosy, seizures and other forms of 'traditional afflictions' are only curable 'traditionally'. ${ }^{69}$ The 'indirect rule' system employed by the British also ensured the continued relevance of the Batombu traditional political system and institutions. Thus, although overwhelmed by colonialism and other foreign influences; the traditional socio-cultural, economic and political institutions of the Batombu were able to respond to these changes, adapted to them and survived their onslaught. Herein lies the changes and continuity among the Batombu.

\section{References}

Aboyeji, S. Oye (2005), "The Impact of Colonial Rule on Indigenous Culture and Institutions of Isin Land", M.A. Thesis, University of Ilorin

Adekunle, O. Julius (2004), Politics and Society in Nigeria's Middle Belt.Borgu and the Emergence of a Political IdentityI, Trenton: Africa World Press Inc.

Alade,C.Aderele (1988), "Some Aspects of Yoruba Culture in Diaspora" in Ogunremi, Charles Aderele\&AdeniranBiodun(eds) Culture and Society in Nigeria, Ibadan: Rex Charles Publications

Anene, J.C. (1960), International Boundaries of Nigeria, 1885-1960: The Framework of an Emergent African State, London: Longman

Appiah, K. Anthony (1998), "Africa: The Hidden History", The New York Review of Books, 17 December 1998 Issue

\footnotetext{
${ }^{68}$ Mathieu Kérékou served as the President of Benin from 1972 to 1991 and 1996 to 2006
}

${ }^{69}$ Oyoru, Ahmadu, Gwanaru, interview: 5 September 2017 
Arowolo, Dare (2010), "The Effects of Western Civilization and Culture in Africa", Afro-Asian Journal of Social Sciences, 1(IV), 12-24.

Atanda, J.A. (1980), "The Historian and the Problem of Origin of Peoples in NigerianSociety", Journal of the Historical Society of Nigeria, 10(3), 33-41

(1980), An introduction to Yoruba History, Ibadan: Ibadan University Press

Batoma, Atoma (2009), "Onomastics and Indirect Communication among the Kabre of Northern Togo", Nordic Journal of African Studies, 18(3), 215-234.

Beck, Sanderson, West Africa and the British 1700-1950 retrieved from http://www.san.beck.org/16-10-WestAfricaBritish.html on 22 December 2017

Blench, Roger and Dendo, Mallam (2004), "The Benue-Congo Languages: a Proposed Internal Classification: Working Document" Cambridge (printout)

Carole, Davies B. (ed.) (2008.) 'Benin', Encyclopedia of African Diasporal. Origins, Experiences and Culture, California: ABC-CLIO Inc.

Chukindi, Joe, "One to 4,000 doctor ratio unacceptable - MDCAN tells FG", Daily Post, 21 January 2018. See also "Doctor-People Ratio Improving, Shortage of Specialists Persists", Financial Tribune, 7 February 2017 retrieved from https://financialtribune.com/articles/people/59036/doctor-people-ratio-improvingshortage-of-specialists-persists on 10 December 2017

Coleman, James (1971), Nigeria: Background to Nationalism, Berkley, Los Angeles \& London:University of California Press

Damakowo, B. Sime (2017), Interview: 22 October 2017

Fafowora, Dapo (2013), "Lord Lugard and the 1914 Amalgamation of Nigeria", The Nation, 14 February 2013

Fage, J.D., A History of West Africa, Cambridge: Cambridge University Press, 1969.

Frobenius, Leo (1913), The voice of Africa: being an account of the travels of the German InnerAfrican Exploration Expedition in the years 1910-1912, London: Hutchinson

Greenberg, Joseph Harold, (1963). The Languages of Africa, Indiana: Indiana University Press

Haddock, N.L. (1959), "The Tones of Bariba", Phonetica: International Journal of Phonetic Science, 3, 90-95

Herbst, Jeffrey (2004, States and Power in Africa. Comparative Lessons in Authority and Control,Princeton \& Oxford: Princeton University Press

Hirshfield, Claire (1979), The Diplomacy of Partition. Britain, France and the creation of Nigeria, 1890-1898, London: MartinusNijhoff 
Hussaini, Lafia (2003), TheBatombu and their Culture, Ilorin: Haytee Press \& Printing Co.

Idris, Abdullahi, the Protocol Chief (Sinadunwiru) of Okuta,interview: 20 October 2017

Katheer, Ibn (n.d: translated by Darussalem Publishers), Life and Times of the Messengers, n.p: Darussalem Publishers.

Kilishi, O. Abdullahi, (Chief of Gure), interview: 2 October 2017

Levtzion, N. (1968), Muslims and Chiefs in West Africa. Oxford: Clarendon Press

Lockhart, J. Bruce (2008), A Sailor in the Sahara: The Life and Travels in Africa of HughClapperton, Commander PN, London \& New York: I.B. Tauris

Lopiz, M. Joan, "Bariba" in Skutsch, Carl (ed.), Encyclopaedia of the World's Minorities, 1, New York \& London: Routledge, 2005

Lovejoy, E. Paul \&Hogendorn, J.S. (1990), "Revolutionary Madhism and Resistance to ColonialRule in the Sokoto Caliphate, 1905-6", The Journal of African History, 31(2), 217-244

Mahmud, S. Saka (1976), "Effects of Modernization on Social Identity:The Borgu Case", unpublished B.Sc Dissertation, Ahmadu Bello University.Zaria, June

Mangut, N. Benedicta (2013), "Preliminary Investigations of the Origin and Historical Traditions of the Borgu in Niger State of Nigeria" Journal of Tourism and Heritage Studies, 2(2), 1-13

Markovitz, I.L. (1970), “Africa's Dual Heritage: Imperialism and Pre-Colonial Greatness" inMarkovitz, I.L. (ed.), African Politics and Society, New York: The Free Press

Mason, Michael (1969), "Population Density and Slave Raiding: The Case of the Middle BeltofNigeria”, Journal of African History.10(4), 551-556

Mathew,A. B.( 1950), “The Kisra Legend” African Studies, 9(3), 144-147

Mautana, H. Mohammad and Kandhelvi, Yusuf (1999: translated by Bosworth, C.E.), The Lives of the Sahabah (translated by Atzal, M. Hoosen), n.d; n.p.

Murdock Matt and Sarah, "Bariba of Togo", http://www.peoplegroups.org/Explore/groupdetails.aspx?peid=14319

Negri,Eve (1964), "Tribal Marks: A Decorative Scars and Painted Patterns" NigeriaMagazine, 10

Obayemi, Ade (1985), "The Yoruba and Edo-speaking Peoples and Their Neighbours Before 1600" in Ajayi J.F.A. \& Crowder, Michael (eds.), History of West Africa, Vol. II, London: Longman. 
Ojo, E.O. (2001), "The Origins of the Yorubas within the Context of the Hamitic Hypothesis" UNAD Journal of Education, 2(1), 69-74

(2002), "The Creation and Migration Myths of Yoruba Origins: AnAppraisal" AAU: African Studies Review, 1(1), 85-96

(2006), "Linguistics: An Indispensable Tool in the Reconstruction of Early Nigerian History", AJOLL: Ado Journal of Languages and Linguistics, 1(1), 21-34

Oluniyi, Olufemi (2017), Reconciliation in Northern Nigeria. The Space for Public Apology,Lagos: Frontier Press

Oyoru, Ahmadu, Gwanaru, interview: 5 September 2017

Poulsen, Sven (1981), “African History: from a European to an African point of view”,Kunapipi, 3(1), 75-80

Prunier Gérard (2003), "Évolution des Critères de definition ethnique en Ouganda" in Chrétien Jean-Pierre and Prunier Gérard (eds.), Les ethnies on tune histoire, Paris: Karthala

Sabikpasi, Umar Sarikin, (Emir of Yashikira), interview: 7 September 2017

Stewart,M. H. (1980), "The Kisra Legend as Oral History”, The International Journal of.African Historical Studies, XIII(1), 23-34

Temple, O. (1919), Notes on the Tribes, Provinces, Emirates and States of the Northern Provinces of Nigeria. Cape Town: Argus Printing and Publishing Co Ltd.

Tibeaderama, P.K. (1977), “The Dissolution of A Kingdom: The Independent District of Illo 1894-1914”, Savannah, 6(1), 11-21

Uya, EdetOkon (2004), African History. Some Problems in Methodology and Perspectives, Calabar: CATS Publication

Williams, Stephanie (2011), Running the Show. Governors of the British Empire, London: Penguin

Williamson, Kay (1989), "Niger-Congo Overview" and "Benue-Congo Overview" in Bendor-SamuelJohn (ed.), The Niger Congo Languages, Lanham: University Press of America, 3-46 and 246-274

Wlemers, E. William (1952), "Notes on the Structure of Bariba", Language, 28(1), January-March, 82-103

Yar-Shater, Ehsan, The History of al-Tabai Vol. V.The Sãsãnids, the byzantines, the Lakmids, and the Yemen, New York: State University of New York Press 